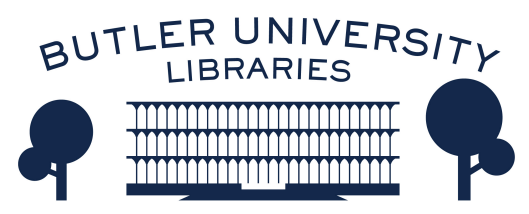

Journal of Hindu-Christian Studies

Volume 25

Article 10

November 2012

\title{
Viewpoint: Reflections on Ludic Dimensions in Hindu-Christian Scholarship
}

Kenneth R. Valpey

Follow this and additional works at: https://digitalcommons.butler.edu/jhcs

Part of the Religion Commons

\section{Recommended Citation}

Valpey, Kenneth R. (2012) "Viewpoint: Reflections on Ludic Dimensions in Hindu-Christian Scholarship," Journal of Hindu-Christian Studies: Vol. 25, Article 10.

Available at: https://doi.org/10.7825/2164-6279.1516

The Journal of Hindu-Christian Studies is a publication of the Society for Hindu-Christian Studies. The digital version is made available by Digital Commons @ Butler University. For questions about the Journal or the Society, please contact cbauman@butler.edu. For more information about Digital Commons @ Butler University, please contact digitalscholarship@butler.edu. 


\title{
Viewpoint: Reflections on Ludic Dimensions in Hindu-Christian Scholarship
}

\author{
Kenneth R. Valpey \\ Oxford Centre for Hindu Studies
}

AS scholars committed to explore and illuminate the varied regions of thought and practice, text and image, or prescription and custom circumscribed by the rather curious samāsa "Hindu-Christian," we may do well to pay more thoughtful attention to ludic features of the landscape. Several decades ago Johan Huizinga counted the inclination to play to be so definitive of being human as to merit reference to our species as homo ludens. Happily, some attention is already being given to this in the area of South Asian religion, as Selva Raj and Corinne Dempsey have shown with their edited volume, Sacred Play: Ritual Levity and Humor in South Asian Religions (SUNY 2010). This collection includes chapters focusing on particular Hindu and Christian ritual practices wherein "levity" of one form or another is highlighted. The editors propose a six-part typology of levity, namely, vertical, horizontal, transgressive, restorative, redemptive, and competitive levity. This is interesting, and it leads me to wonder if there are not more types of levity to be identified, especially if we allow the possibly broader term "play" to come to the fore. Here my argument is simple: Let there be more such work (or play) in the area of the ludic, as an important means of stretching our understanding of where these two traditions-Hindu and Christian-meet, where they part company, and how persons (including scholars of Hindu-Christian studies) go about relating the two traditions. As a "side benefit" we may find attention to the ludic dimensions of Hindu and Christian traditions helpful in our teaching enterprises: students are usually open for a good laugh, especially if it offers a rich insight.

One thought I gleen from the Sacred Play article collection might be obvious to any reader-that Hindu and Christian traditions taken separately and then together can indeed provide rich fields for appreciating how play, with all its related terms, is "played out" or "works" within and among these traditions. These and further explorations in the light side may also help appreciate more deeply (and more seriously) the "playful" character of our scholarly enterprises as we stride back and forth across the hyphen-bridge with which we codify the web of links we find or create between the two tradition-constellations: Comparison-as-play. As J. Z. Smith notes in his Response that concludes Sacred Play, there is a lexical link between "levity" and "leverage." In scholarship as in life, levity often serves to broaden one's perspective, serving as a tool to nudge "heavy" objects into new felicitous positions for viewing and comprehending.

A broad attitudinal setting for our entry

Kenneth Valpey is a research fellow at the Oxford Centre for Hindu Studies (Oxford University) and has also been a regular visiting scholar at the Chinese University of Hong Kong in the Department of Cultural and Religious Studies' Professorship in Indian Religions. In addition to his book Attending Kṛnna's Image: Caitanya Vaișnava Murti-sevā as Devotional Truth (Routledge 2005) he has published articles and encyclopedia entries on Hindu and Gaudīya Vaișnava thought and practice. In 2006 he presented a paper at the World Sanskrit Conference in Edinburgh, "Bodies Monstrous, Bodies Divine: Corporal Transformations and Humor in the Bhāgavata Purāna," and in collaboration with Dr. Ravi M. Gupta, he is preparing two volumes on the Bhāgavata Purāna (Columbia University Press; the first to be available by April 2013). A future aim is to write on Hindu and Christian understandings and practices related to images (for which he seeks a collaborator, especially someone competent in Orthodox traditions of icon veneration). 
into the ludic dimensions of Hindu-Christian studies may be afforded by John Morreall in his book Comic Relief: A Comprehensive Philosophy of Humor. In considering the negative ethics of humor (chapter 5) Morreall notes three of humor's possible harmful effects, namely, irresponsibility, blocking compassion, and promoting prejudice. It is no doubt the case that members of both Hindu and Christian traditions, particularly in India but also in other parts of the world, in their negative apprehensions of the other tradition, indulge in humor that produces and perpetuates these effects. We do well to take note of such practices, calling attention to them as possible sources of misunderstanding and conflict that could be circumvented by more charitable forms of humor, comedy, and play.

Morreall also identifies (in chapter 6) various intellectual and moral virtues fostered by humor. Open-mindedness, creative thinking, and critical thinking can all be cultivated by a good joke (or a good comic play performance), as can the basic moral skill of selftranscendence and the pursuit of selfknowledge. While such forms of "virtuous" humor are surely discoverable within both Hindu and Christian traditions, we may ask to what extent, if any (beyond the tiny sphere of scholars studying both traditions), they serve favorably to foster understanding across their own self-identified and defended boundaries of what is considered properly "Hindu" or "Christian."

Harmful and helpful effects of humor may be a necessary starting point for considering ludic dimensions in the Hindu-Christian sphere. And then one would surely wish to go deeper (or higher) to consider humor and play as elements of the traditions' spiritualities. On the "outer" or more exoteric side of this area might be located certain types of didactic literature and practices, whereby (not unrelated to the harmful and helpful elements of humor), one learns by laughing - at the folly of short-sighted worldly behavior, or with the world at one's own human frailties (recalling Lee Siegel's distinction in Laughing Matters). On the Hindu side of the hyphen, Sanskrit and vernacular literature is replete with didactic works that make fun of certain character types and personages, including those typically revered within the tradition (I'm thinking of how much the god Indra is made a laughingstock in the Bhāgavata Purāna). Christian didactic and homiletic literature is surely as much charged with humor, beginning with the Gospels' renderings of the Sermon on the Mount as a lesson or series of lessons based on ironic inversion of value that participates in the sphere of surprise which is reminiscent of play (involving the triggering of "cognitive shifts" - common to the perception of humor) including elements of word-play. What, we might ask, can be said with respect to "Hindu didactic humor" or "Christian didactic humor" that would either distinguish them or point to their participation in the larger sphere of "common humanity's" sense of humor? To what extent are they teaching the same lessons by means of humor, and in what ways does humor serve to persuade? What does one need to know in order to "get the joke," and what is presupposed for the respective traditions' humor to "work"?

Going further, we may consider the ways that both traditions acknowledge paradox ("the most energetic means of presenting a truth" Unamuno, in Götz, p. 17) and express it (and relieve it) through humor. Citing Conrad Hyers, in his book Faith, Humor, and Paradox, Ignacio L. Götz calls our attention to the dialectical relationship between the sacred and the comic: "Without this relationship, the sacred tends to become pompous and, eventually, despotic and fanatical; and the comic, similarly, tends to become frivolous and inconsequential" (p. 7). The sacred is, he suggests further, a search "for the openness to whatever beckons beyond the limits of systems," all of which by their very nature are fundamentally incomplete. Paradox is the perception and expression of the limits of systems, and the challenge to break through them to a greater truth.

A classical Christian expression of paradox is Tertullian's Credo quia absurdum, usually considered to be an admission of faith's irrationality but, Götz argues, in fact an assertion of truth's paradoxical nature, paradox being in turn faith's very structure. Akin to the paradox of divine incarnation is the notion of Christ's folly and the broader Christian 
tradition of the holy fool, rooted in the inversion of values inherent in the Christian vision. A further step in considering folly as wisdom may take us to the notion (argued by Bruce Chilton in his book Rabbi Jesus: An Intimate Biography), that despite the lack of evidence in the Gospels for Jesus having laughed, Jesus must have participated in mirthfulness, being a man "who substituted convivial feasting for the asceticism of the Baptist's immersion" (Götz, p. $3)$.

That ultimate truth is sustained in paradox seems to impell many of the extended quests for truth celebrated in some of the world's best literature, of which the grand Christian literary account, Dante's Divina Commedia comes immediately to mind. That this epic poem is called a comedy is doubly significant: Not only does the hero eventually reach beatitude in his audience with God in Paradisio, but the reader/listener is invited beyond the "limits of systems," far from the frivolity and inconsequentiality associated with much humor.

As for grand truth-quests in Hindu traditions, one might begin by recalling episodes in various Upanișads, where the somber search for and realization of atman and brahman are typically represented as dialectical undertakings that partake of the humorous. Thus, for example, we may recall Yama's embarrassment for failing to properly greet Nāciketas at his underworldly home, and his further discomfort at being forced to fulfill the latter's wish to hear of the self's destiny after death (in the Katha Upanișad). Or in the Chandogya Upanișad there is the protracted process of instruction given by Prajāpati to Indra and Virocana on the nature of the self, such that only after three times returning (over 101 years) does Indra finally "get" the truth he seeks.

In Sanskrit literature the search for God may be said to reach a high point in playfulness (both narrative and verbal) in the Bhāgavata Purāna, especially in its tenth book Rāsapañcādhyāya - the five-chapter (29-33) account of Kṛșna's meeting, disappearance from, and again meeting and dancing with, the Vraja Gopis, the cowherd girls identified as Kṛșna's eternal consorts. In the well-known description of the Gopis' mad search for absent Kṛṣna, they address the forest flora in hopes of gaining clues to his whereabouts, and then, becoming even more distracted, they act out sketches of his various activities, thereby imitating his mannerisms. Later (in chapter 47), after the divine trickster Krșna has departed from Vraja altogether, one Gopi speaks distractedly to a bumblebee, taking it as a "messenger" from Krṣna that deserves the full force of her scolding words. Such artful banter, stretching as it does the notion of divine perfection almost to the breaking point, fits well, as readers of this journal are likely to know, with the Hindu notion of divine play - lì $\bar{a}$ - that gets so much Indic theological mileage in explanations of relationality between God and world, and between God and humanity. Even if J. Z. Smith is "grateful" that the authors in Sacred Play have avoided "invoking the usual appeal to a cosmologized and an ontologized notion of lila (divine play) as an explanatory principle" ( $p$. 211), the concept's importance in Hindu theological thought can hardly be ignored.

My initial thoughts on the possibility of parallels to the notion "divine play" in Christian traditions lead me admittedly away from theology to music. The "playfulness" of a Bach fugue surely aims to point its listeners in the direction of divine glory in a way that suggests the element of play; and equally, though radically different in style and mood, the soulful congregational singing in Baptist and Pentacostal churches active in India may do the same. Then there are the numerous Christian celebrations and feasts (returning to Chilton's point), more expressive of joy, levity, and anticipation of beatitude, than of somber recollection of divine suffering.

What may be important for considering Hindu and Christian understandings of play in parallel is that, whereas the narrower term "humor" can have good or ill effects, in many of its manifold forms play can be understood to transcend dualities typically associated with religion. Huizinga writes: "Play lies outside the antithesis of wisdom and folly, and equally outside those of truth and falsehood, good and evil. Although it is a non-material activity it has no moral function. The valuations of vice and virtue do not apply here" (Homo Ludens, 1949, p. 
6). Furthermore, insisting that play cannot be "explained" by any utility, Huizinga notes, ". . . to presuppose the utility of play from the start is to be guilty of a petitio principii. Child and animal play because they enjoy playing, and therein precisely lies their freedom" (ibid., p. 8). And yet - and here comes a possible paradox - play is always bound by an explicit or implicit set of rules, the non-observance of which immediately ends the play. This may be the case even when the central rule is, as in certain forms of Tantra, to flaunt all the rules of mainstream society.

Can we discover and articulate patterns of rule-governance for the several types of play observable in Hindu and Christian traditions? How, then, might the discernment of such patterns help to get us across the sometimes gaping (and sometimes narrow) hyphen with which we tie the two traditions together? Do the rules of play in one tradition parallel the rules of the other, or do they counter them, or do they suggest "room for play" between the two traditions, allowing space for unsettling the categories sufficiently to invite recognition of a bigger picture than either alone or both together can contain?

Finally, in considering the ludic dimension of Hindu and Christian traditions, we should not ignore the various ways they are mocked from secular quarters. We have seen Monte Python's spoof on the life of Jesus, The Life of Brian (deemed one of the best comedy films ever), and we have seen Newsweek sporting a multi-armed Barrack Obama in seeming parody of Hindu-armed divinities. Sita Sings the Blues, with its creator Nina Paley's very personal and painful story woven into a sort of Rāmāyanalite, gives a fresh look at the story of Rāma through the eyes of a modernized Sitā. And India's The Week (Feb. 19, 2012) publishes a parody from de Vinci's "Last Supper" produced by members of the CPI(M) in Kerala-again with Obama featured, surrounded by his capitalist cronies. What can be understood about these sorts of play and their effects on various audiences? More broadly, what does the existence of such humor say about the proneness of religious traditions in our "secular age" to such critical stances? Such questions may be especially relevant in relation to HinduChristian studies, focused as they are on a part of the world-South Asia-that is typically characterized by its rapid secularization and concommittent globalization. It is especially here that the sacred/secular dichotomy may find its strongest antedote in the form of humor and play. 